\title{
University Students' Attitudes towards E-Learning: University of Business \& Technology (UBT)-Saudi Arabia-Jeddah: A Case Study
}

\author{
Abdelrahim M. Zabadi ${ }^{1} \&$ Amr Hussein Al-Alawi ${ }^{1}$ \\ ${ }^{1}$ Dahban Campus, University of Business and Technology, Saudi Arabia \\ Correspondence: Abdelrahim M. Zabadi, Dahban Campus, University of Business and Technology, Saudi Arabia. \\ E-mail: azabadi_2011@hotmail.com
}

Received: March 27, 2015

Accepted: April 8, 2016

Online Published: May 25, 2016

doi:10.5539/ijbm.v11n6p286

URL: http://dx.doi.org/10.5539/ijbm.v11n6p286

\begin{abstract}
Through the World Wide Web, education has become a ubiquitous service delivered anytime anywhere. Campus-based and without distance learners, higher education institutions attempt to fulfill the requirements of e-learning in conventional course transmission, to prepare students, staff, and educational institutions for the future involvements in educational processes. The study was conducted to examine attitudes of UBT students' in Dahban and Sari campuses towards e-learning by taking (371) students from four colleges and English language center.

In sampling techniques, we used the stratified random sampling in choosing the study sample. To gather the primary data from respondents, a well-structured questionnaire, developed by the researchers. The findings indicated that UBT participants' owns a high standard on attitude towards e-learning and their attitude results are significantly vary with their gender, technology usage and skills.
\end{abstract}

Keywords: E-learning, attitude, gender, student, UBT

\section{Introduction}

The rapid development and wide-spread usage of e-mail; chat rooms; social networks; interactive multimedia applications; web conferences; and internet technologies, as a result the internet effectively used in educational environment (Yamamato, DEmiray, \& Kesim, 2011; Yapici \& Akbayin, 2012). This evolution led to creating a modern educational environment like: electronic and distance learning, and online learning-Learning includes several approaches and employments through web-based and computer-based learning, digital cooperation, and practical classes. Thus, e-learning recently is acceptable as a comprehensive modern concept that indicates to training based on different electronic equipment's and multimedia (Hazendar, 2012).

The experiences obtained from e learning in the long term provide a valuable opportunity to educational institutions for getting new and modern areas for this type of education. Likewise, those systems of education have enabled students to access several diverse contents anytime, anywhere. This allows the learners further dominance on their learning experiences, and qualifying the learners to collect the educational courses the students need, and study where as they have enough time (Bhatia, 2011).

In the current era, the internet has become more competent in helping individuals in everyday life activates, for this reason; it is globally utilizes in different fields of education, which becomes potential and appropriate. Very briefly, the extensive usage of computer technologies and internet had led to the acknowledgement of this technology in many different educational fields. Employing the technology as teaching and learning appliances has become to an increasing extent more wide-spread; the teaching materials are enriched and have been requested as a part of educational processes and even a priority objective (Yalman, GÖnen, \& BaȘaran, 2013).

Various educational institutions around the world combine e- learning platforms to come upon the essential necessity of the rapid increasing of students' numbers who is searching for the appropriateness of online courses and to keep compete in quickly changeable educational environment and available opportunities. E- Learning offers opportunities to encourage education towards generate an environment where group of students and teachers can share their experiences and awareness.

Therefore, it is extremely significant to layout an effective e-learning scheme for instructions, education, human resources, and well - trained administration staff for higher education (Nelasco, Arputharaj, \& Paul, 2007). 
However, the major important question is here: Does that educational institution and students are willing to adopt e-learning facilities through their advancement? To answer this question, investigators attempted to verify the attitude of UBT students toward e-learning.

Several researches conducted to measure the influence of demographic on students' attitude towards e learning. Likewise, previous researches reports that the primary factors participating in internet usage are socio-demographic characteristics such as gender, rather than socio-economic characteristics like monthly salary, level of education, or another psychological factors (Nassoura, 2012).

In Developing countries, university student's attitudes vary towards e learning, but in general, we can say that their attitudes are positive. This was emphasized by (Nassoura, 2012) who expressed that the majority of students have a favorable behavior toward the e-learning, since, the e-learning had a positive influence on students' motivations (Nassoura, 2012).

The demographic characteristics and technological skills are considered as global problem to the learners; therefore, understanding users' personal characteristics and e-learning systems usage is necessary to introduce an effective e-learning.

As for student's factors, the researchers focused on investigating students' characteristics regarding to their gender, and technology experience and skills also. Previous studies show that there is a rareness of researches about student's individual differences such as Gender, Technology Usage and Skills. This research wishes to fallout this void in similar literature. The research is structured as following; the following section introduces the background, followed by research objectives, questions, and methodology. Finally, discussion and conclusions, suggestions for future researches are also included.

\section{Theoretical Background}

In this part of the study, we will present some related previous studies on the variables under consideration. Many researches investigate the influence of demographic profiles such as computer ownership, age, gender, education, personal skills and computer and internet on university students' attitude towards e-learning (Paris, 2004).

\subsection{E-Learning}

Developments in the field of science and technology influenced the education as many other scientific areas. For this, it becomes very important to expand the technological infrastructure for educational institutions, particularly as the methods and technologies of education changing quickly.

Internet usage and developed social media interactions by means of the internet technologies has influenced the technology facilitated the pedagogical services. Accordingly, our everyday lives have turn into technology centered more and more (NCTM, 2000). Pedagogic organizations, which are responsible for preparing learners to the future, making further technology utilization through enhancing curriculum. Computer usages assisted instructional systems (Chang, 2002), animations (Lin \& Atkinson, 2011), emulation, and 3-D virtual environments have become familiar (Rafi, Samsudin, \& Ismail, 2006).

Other adequate contribution of current technology growth for education is the widening of e-learning environments. With use of advancements in technology and communications, including visible and audial responses has become probable in the learning environment; e-learning environments offer lifelong learning opportunities by removing socio-economic discrepancies (Duran, Önal, \& Kurtuluş, 2006).

Advantages of e-learning are: the learner determined the time of learning; materials can be accessed anytime, anywhere via internet connectivity; speed, time, and the amount of courses can decide by e-learners themselves; materials and information is already able to be obtained and can be regenerated; efficiency of the education can be assessed immediately; courses criteria can be dependently obtained by students; teachers are obtainable permanently through e-mail; forums, web, etc.; costs instructional costs were reduced (Gülbahar, 2012).

The expression electronic learning includes widely vision of educational instruments and methodologies that continue to meet the students and educators needs a like. Global communications and internet rapidity, the growth of web content became more and more interactive for end users. Systems of e-learning supplies additional adaptable methods of communicating that qualifies student has to inter act easily together (Spender, 2001). Newton (2003) suggested that systems of e-learning includes three major fields: enhancing accessibility to the beast learning and training; improving quality of education and study; and the necessity for higher education institutions (HIEs) to obtain competitive quality in changeable environment within the field of education (Newton, 2003). 
Additionally, e-learning platform based on the network motivates accumulation of individual acquaintance, sharing of knowledge amongst learners, and therefore, strengthen the competitiveness of individuals and the group. In total, the e-learning platform looks like an advanced step towards education of with high-efficiency and better quality.

E Learning, particularly the utilize of learning management systems (LMSs), introduced a modernistic side. Investigators proposed that some learners and trainers might have insufficient skills and experience to use web-based learning platforms effectively (Brüchner, 2003). This concern is often researched in the context of gender variation. Primary issue is that female students are at a disadvantage due to different patterns of computer use (Richter, Naumann, \& Horz, 2001).

\subsection{Gender}

Literature suggests that gender represents critical part in realizing the variation in perceptions towards technology skills and attitudes on e-learning; numerous researches were conducted to explore impact of gender, year of study on student attitudes towards e-learning. Many studies confirmed that student's male owns more positively attitudes towards e learning than female students (Liaw \& Huang, 2011).

Egbo et al. (2011), they concluded that female would accept information and communication technologies (ICTs) use more than males (Egbo, Okoyeuzu, Ifeanacho, \& Onwumere, 2011). Liaw and Huang (2011) their findings confirmed that male owns a positive attitude toward e-Learning than female. Furthermore, the researchers proposed that experiences and skills in computer is an important indicator on learners' motivation toward e-learning.

Cheng (2006) believes that individual characteristics like gender, computer skills are not enough. Computer experience and skills played a primary factor in influencing on students' attitudes about e- learning (Cheng, 2006) also, identified characteristics like age, gender, computer experience, technology acceptance, and individual learning styles as principal factors when investigating the students attitudes concerning e-learning processes. Katz et al. (1995) stated that "no important variation between attitude scores for male and female".

Suri and Sharma (2013) clearly expressed that "no gender variations about the attitudes towards e-learning". These result fit with several new studies which exposed that the gap between male and female in this issue is narrowing (Bhattacherjee, 2008).

Yacob et al. (2012) examined the familiarity of university students' in e learning, discussion of analysis were carried out on the students' perceptions regarding to gender, technology usage and the knowledge about e-learning implementation. Results shows that gender have a significant effect on attitudes towards e-learning (Dørup, 2004), 46\% of males from first-year students prefer replacing "traditional learning" by using computer in learning, while only $22 \%$ of women support this result.

Liaw and Huang (2011) explored the individual's attitudes and behaviors in utilizing e-learning regarding to gender differences, computer skills. A result shows that male learners have additional positive attitudes towards e- learning than female students, and experience in computer usage is a significant index on learners' attitude toward e learning.

According to Sebnmen (2015), the mean score of female attitude toward e-learning is higher than those of the male are; difference between the mean scores not found to be statistically significant. Gender did not significantly affect student's attitudes towards e- learning did not significantly affected by gender.

Dhiman et al. (2014), mentioned that male and female students own a high attitude towards e-learning although female students have slightly higher attitude towards e-learning than their male counterpart (30).

This finding is consistent with work of Mehra and Omnidan and Adewole-Odeshi who found that postgraduate students have high positive attitude towards e-learning. These results supported by the work of (Paris, 2004; Colley, 2003; Liaw et al., 2011) but not support the work of (Bhubaneswari \& Padmanaban, 2012) who found that male and female students possess different attitude towards e-learning.

\subsection{Technology Usage and Skills}

The past few decades have witnessed an increasing interest in using computers in educational establishments in developing countries. The use of the Web networks, computer and mobiles acquired an interest between learners who utilize these tools for pedagogical objectives. This suggests that students have a high degree of computer skills and use its various applications. The students' ability to use Internet and communication Technologies (ICTs) was significantly hindered by the low level of technology access (Husain, 2007).

Bhuasiri et al. (2012) found that the greatest important factors concerning the growing technology knowledge 
and improving behavior to e-learning, promoting principal technology familiarity and expertise, improving study content, demanding computer training, motivating users to utilize e-learning systems, and requiring a high degree of support from the institute (Bhuasiri, Xaymoungkhoun, Zo, Rho, \& Ciganek, 2012).

In addition, attributes used to assess the attitudes towards ICT of students, teachers and principals have been categorized in two groups: demographics such as age and gender and computer skills and experience Papaioannou and Charalambous (2011) Many studies identified a positive correlation between computer experience and attitudes toward e-learning (Papaioannou, \& Charalambous, 2011).

\subsection{Attiudes}

The attitude toward e-learning can be viewed as a an umbrella for the methods of education supported by ICT, and specified with the consent or lack of consent of the students or lack of consent on the importance of technology and their special skills. Besides that, students' attitude towards e- learning affected through what they see as the advantages and disadvantages for this type of education.

Bertea (2009) talking about e learning, a favorable attitude shows a greater probability that learners will accept the new learning system. Factors such as patience, self-discipline, easiness in using software, good technical skills, and abilities regarding time management impact on student's attitude towards e-learning, thus, the attitude can be positive, if the new form of education fits the students' needs and characteristics, or negative if the student cannot adapt to the new system because he does not have the set of characteristics required (Bhatia, 2011).

\section{University of business \& Technology (UBT)}

UBT is the leading private institution in the area of business and technology in Jeddah City / Saudi Arabia. UBT has grown progressively from a beginner College to a full four-year college, college of Business Administration (CBA). The launch of Faculty of Engineering and Information Technology (CEIT) in 2008, College of advertising (JCA) joined after approved by Saudi MOHE in 2011 as the third faculty. In 2012, the Higher Council of the Saudi Higher Education formally stated UBT as the University of Business \& Technology.

As the technology is advancing, the need of the university faculties', staff, and the growing number of students, the demand of e-learning is also increasing, for this, UBT has to cope with these technological and human developments by improving and developing its own technology tools particularly in education and training programs.

UBT e-learning vision is "to become the first university of e-learning education in the area" according to the university president professor Hussein Al-Alawi. This is achieved by creating an environment where the use of ICTs is regarded as an integral part of the university practices and management of educational process.

UBT e-learning mission is "to promote an e-learning phenomenon where students, teachers and investigators utilizes technology to develop the total pedagogical experiences in campus and off campus alike", as the president mentioned. This is achieved by provide quality of education that is accessible anytime, anywhere ,as well as to encourage and support the effective use of technology in the curricula through continuous improvements in existing programs and the creation of new technology opportunities for students, instructors , administration and faculty as a whole.

\section{Study Objectives}

This study seeks to achieve the following goals:

1) To reveal whether attitudes of UBT students towards e-learning varies according to gender.

2) To locate whether attitudes of UBT students towards e-learning varies according to student's use of technology and skills.

3) To investigate the overall attitudes of UBT students' towards e-learning.

\section{Study Questions}

In line with those objectives, questions below were formulated:

1) Are there significant differences in attitudes towards e-learning according to the gender?

2) Are there significant differences in attitudes towards e-learning according to student's use of technology and skills?

3) What are the overall attitudes of students towards e-learning? 


\section{Study Hypotheses}

To study university students' attitudes towards e-Learning, the following research question is proposed: "What are the overall attitudes towards e-learning in UBT?" In relation to above research question, the following three hypotheses have been formulated:

The first Hypothesis (H1): There are no statistically significant differences in attitude towards the e-learning according to gender.

The Second Hypothesis (H2): There are no statistically significant differences in attitude towards e-learning based technology usage and skills.

The Third Hypothesis (H3): UBT students' attitude towards e- learning is low.

\section{Research Methodology}

\subsection{Population}

This study employed a questionnaire to examine the attitudes of students towards e-learning. The target population was the students of UBT, Dahban and Sari campuses, Jeddah, Saudi Arabia. A total of (402) questionnaires were distributed in College of Engineering and Information Technology (CEIT), College of Business Administration (CBA), and college of Graduate Studies (MBA), College of Advertising (JCA), in addition to English Language Center (ELC). (402) questionnaire were collected, (31) of those were neglected because they were in complete. (371) found statistically usable for this study representing a respond rate of $(92.3 \%)$. A reliability coefficient is more than $(0.70)$ indicates that the items used in the study are reliable.

\subsection{Instrument}

Questionnaire composed from three parts. The first part includes the respondents' demographic profile such: as gender, age, and college. This was followed by (15) items on computer practices and skills related to e-learning tools and activities, while the third part is the statements of overall attitudes towards e-learning, consists of (11) items, each rated on five-point Likert scale running from $(1=$ Strongly disagree, $2=$ Disagree, $3=$ Undecided, 4 $=$ Agree, and $5=$ Strongly Agree). For this study, experts in the field ensured face and content validity of the items through consultation.

\subsection{Procedures}

Questionnaire was distributed during the classes under supervision of the lecturers and co-authors on a voluntary basis. An objective of the questionnaire is clear for all participants and aims. Participants were asked to fill in questionnaire during the lecture. It was ascertained that participants should not write their names or putting any distinctive mark on the questionnaire.

\section{Data Analysis}

\subsection{Sample Characteristics}

This section will discuss the demographic characteristics of the participants (gender, age, and college).Data indicates that $(76 \%)$ are male, and (24\%) are female, Figure 1. Majority of respondents aged between (20-26) years old $(58 \%),(19 \%)$ were less than 20 years old, $(19 \%)$ were between $(26-30)$ years old, and $(4 \%)$ were greater than 30 years old, Figure 2. The distribution of student according to colleges, results indicated that: (33\%) from CBA, (29\%) from CEIT, (20\%) from ELC, (10\%) from MBA, and (8\%) from JCA, Figure 3.

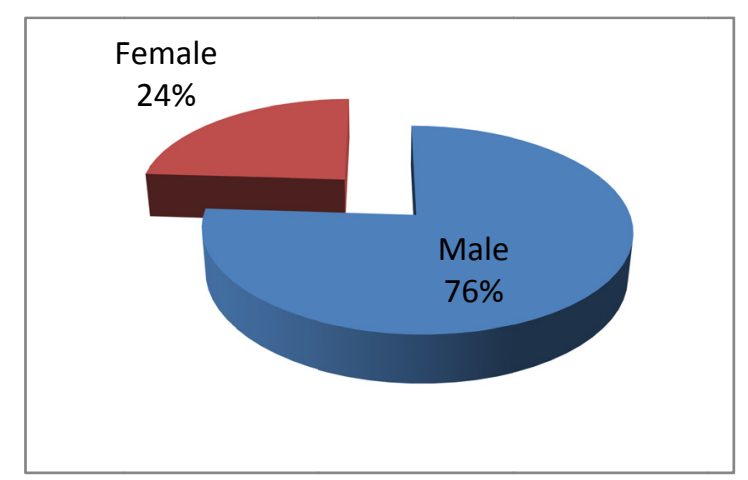

Figure 1. Respondents' distribution according to gender 


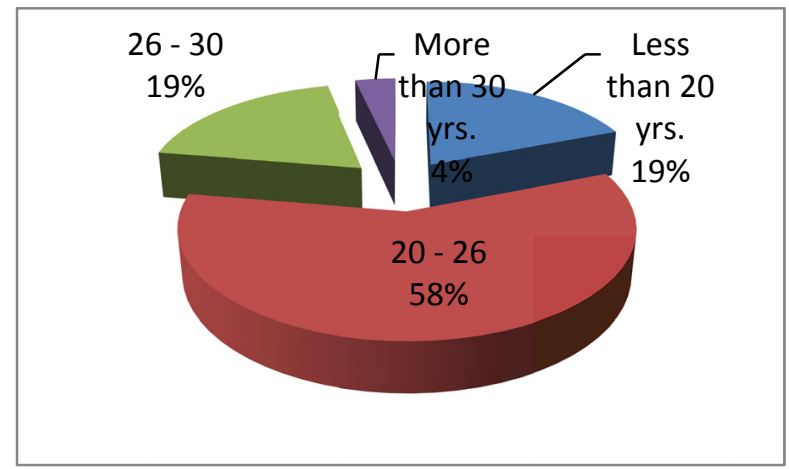

Figure 2. Respondents' distribution according to age

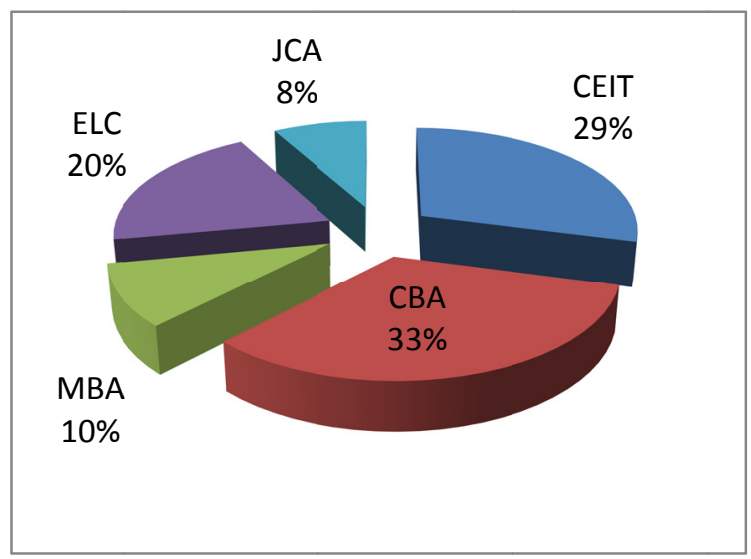

Figure 3. Respondents' distribution according to college

\subsection{Statistical Results}

Descriptive statistics (Means and Standard Deviations) of sample's responses regarding perception of variables.

Table 1. Technology usage and skills

\begin{tabular}{lll}
\hline Questions & Mean & Std. Deviation \\
\hline I feel comfortable in my ability to do with computer technologies. & 3.8 & 1.05465 \\
I like working with computers. & 3.8 & 1.00126 \\
I do not feel threatened by the effect of computer technologies. & 3.6 & 1.18683 \\
I prefer to employ computer to wright my assignments. & 3.6 & 1.17251 \\
I would like to choose to use computers in my learning. & 3.6 & 1.04331 \\
I usually use Internet during my self- study. & 3.9 & 1.00658 \\
Normally, I download learning content from Internet. & 3.7 \\
Reading e-book is favored for me. & 3.1 \\
I download pictures, graphs, reports, assignments, course materials, presentations from Internet. & 1.22422 \\
I face several problems while using the internet. & 3.8 \\
I use electronic library in my self-study. & 3.2 \\
I prefer to transfer the educational materials electronically (by e- mail) to my colleagues, friends, and teachers. & 3.05846 \\
I feel satisfied and joy full when educational material collected from Internet. & 3.6 \\
I use different educational blogs for interaction. & 3.5 \\
Over all, I feel at ease learning by computer technology. & 1.15218 \\
Total & 3.3 & 1.11618 \\
\hline
\end{tabular}


Table 2. Overall attitudes

\begin{tabular}{|c|c|c|}
\hline Questions & Mean & Std. Deviation \\
\hline I am interested in studying some courses that utilize e-learning. & 3.6 & 1.14673 \\
\hline I think that e-learning promotes my learning experiences. & 3.8 & 1.78975 \\
\hline Presenting courses on the internet, makes learning more efficient. & 3.6 & 1.04327 \\
\hline I intend to use e-learning tools during the semester, if available & 3.6 & 1.00526 \\
\hline I am positive about e-learning. & 3.7 & 1.04590 \\
\hline E-learning environment needs advanced technical knowledge. & 3.7 & .98498 \\
\hline I would prefer to have some courses on the internet, rather than in classroom (face-to-face). & 3.3 & 1.23669 \\
\hline Online Learning is more comfortable and enjoyable to me. & 3.2 & 1.15242 \\
\hline E-learning is a favorable alternative to the pen-paper based system. & 3.3 & 1.13616 \\
\hline E-learning is not efficient as a learning method. & 3.3 & 1.10268 \\
\hline Over All, I prefer e-learning and I believe that it is better than traditional method of learning. & 3.4 & 1.21788 \\
\hline Total & 3.5 & 1.1693 \\
\hline
\end{tabular}

\subsection{Hypothesis Testing}

The Statistical Package for Social Sciences (SPSS) software tests the hypotheses.

First hypothesis: There is no significant difference in attitude towards e-learning according to gender.

Table 3. Test of hypothesis 1

\begin{tabular}{|c|c|c|c|c|c|c|c|}
\hline variable & Gender & $\mathrm{N}$ & Mean & Std. & df & (t) value & $\begin{array}{l}\text { (Sig) } \\
\text { level }\end{array}$ \\
\hline \multirow{2}{*}{ difference in attitude towards e-learning } & Male & 282 & 39.9 & 6.7 & \multirow{2}{*}{369} & \multirow{2}{*}{5.62} & \multirow{2}{*}{$0.001^{*}$} \\
\hline & Female & 89 & 34.4 & 10.6 & & & \\
\hline
\end{tabular}

* Significant at (0.05) level.

The mean of attitude scores for male and female university students is found to be (Mean=39.9) \& (SD = 6.7) and $($ Mean $=34.4) \&(\mathrm{SD}=10.6)$ respectively. It indicates that UBT male and female students have a high attitude towards e-learning although male students possess higher attitude towards e-learning than their female counterpart does.

T-Value (Table 3$)$ is found to be $(\mathrm{t}=5.62)$ at significance level of $(0.001)$ which is statistically significant .Therefore, there is a significant difference in attitude towards e-learning, between male and female student. In view of the above, the Null hypothesis is rejected. Thus, there is a significant difference in attitude towards e-learning, between UBT male and female student. This result supported by the work of (Bhubneswari et al., 2012), who found that male and female university students possess different attitude towards e-learning.

Second hypothesis: There is no significant difference in attitude towards e-learning based technology usage and skills.

Table 4. Test of hypothesis 2

\begin{tabular}{|c|c|c|c|c|c|c|c|}
\hline variable & Gender & $\mathrm{N}$ & Mean & Std. & $\mathrm{df}$ & (t) value & $\begin{array}{l}\text { (Sig) } \\
\text { level }\end{array}$ \\
\hline $\begin{array}{l}\text { difference in attitude towards e-learning based } \\
\text { technology usage and skills }\end{array}$ & $\begin{array}{l}\text { male } \\
\text { female }\end{array}$ & $\begin{array}{l}282 \\
89\end{array}$ & $\begin{array}{l}55.3 \\
50.4\end{array}$ & $\begin{array}{l}8.2 \\
12.5\end{array}$ & 369 & 4.83 & $0.001 *$ \\
\hline
\end{tabular}

* Significant at (0.05) level.

The mean of attitude scores for male and female university students is found to be (Mean=55.3) \& $(\mathrm{SD}=8.2)$ and $($ Mean $=50.4) \&(\mathrm{SD}=12.5)$ respectively. It indicates that UBT male and female students have a high attitude towards e-learning although male students possess higher attitude towards e-learning than female.

$\mathrm{T}$-Value (Table 4) is found to be $(\mathrm{t}=4.83)$ at significance level of $(0.001)$ which is statistically significant. Therefore, there is a significant difference in attitude towards e-learning according to gender. In view of the 
above, the Null hypothesis is rejected. Thus, there is a significant variation in attitude towards e-learning based technology usage and skills .This result supported by (Egbo et al., 2011) who found that both female and male students possess a different attitude towards e-learning.

Third hypothesis: UBT students' attitude towards e-learning is low.

Table 5. Test of hypothesis 3

\begin{tabular}{llllllll}
\hline variable & Mean & Std. & df & $\begin{array}{c}(\mathrm{t}) \\
\text { value }\end{array}$ & (Sig) level & $\mathrm{x}^{2}$ value & $\mathrm{p}$-value \\
\hline attitude towards e- learning level & 3.5 & 1.0421 & 370 & 107.69 & 0.00 & 248.3 & 0.00 \\
\hline
\end{tabular}

* Significant at (0.05) level.

The mean of attitude scores is found to be $(\mathrm{Mean}=3.5) \&(\mathrm{SD}=1.0421)$ and $($ Mean $=34.4) \&(\mathrm{SD}=10.6)$ respectively, $(3.40<3.5<4.19)$. The $\mathrm{t}$ - Value (Table 5) is found to be $(\mathrm{t}=107.69)$ at significance level of $(0.000)$, $\left(x^{2}=248.3\right)$, which is statistically significant. In view of the above, the third Null hypothesis is also rejected.

Thus, UBT students have a high attitudes towards e-learning. This indicates that an UBT student attitude towards e-learning is high. This finding is compatible with the study of (Ahmad Bendania, 2011) which supported that Saudi students have a high positive attitude towards e-learning.

\section{Discussion and Conclusion}

The aim of this study is to examine the UBT students' attitude towards e-learning. The study has examined the impacts of gender, technology usage and skills on students' attitude towards the e-learning. The outcomes from analyses provide strong support the three null hypotheses. In addition, this study has found that the influence of gender, technology usage and skills are statistically significant, this conclusion need to further consideration and testing. UBT students have generally positive attitude towards e-learning, consequently, the researchers can conclude with high confidence that university students are willing to accept many courses via online mode.

The study demonstrate that e-learning is offering a precious opportunities for higher education the institutions (HEIs) to a considerable amount of students who wish in pursuing their education regardless of their, spatial, economical, and social barriers. Teachers have to adopt strategies to change the negative attitudes towards e-learning by introducing further e-learning courses in lower study years and promote students to use the internet in their education and communication with their teachers and their colleagues.

\section{Suggestions for Future Research}

Based on the results of the current study, the researchers would like to suggest the following recommendations.

- The extensive and appropriate use of the internet and modern technologies can make up the lack of campus activities and the rarity of student-instructor interaction.

- Conduct similar studies for further investigation of instructors' attitudes to the e-learning.

- As no other researches consider the variable of academic level for the first university degree, it could be fruitful to outline it for further researches.

- Further research is recommended to identify other variables such as (class level, learning method, and motivation type) that may affect the students' attitudes toward e-learning.

- In addition, it would be advantageous to see that the findings presented in this study could expand to include instructors and institutions to assure the successfulness of the e - learning. This will be beneficial to the persistent evolution of this significant research area.

\section{Acknowledgements}

Many thanks for our students from industrial department: Adnan Hejazi and Mohammed Qadish for their support during accomplishing this study; especially for ethical approval and data collection processes.

\section{References}

Adewole-Odeshi, E. (2014). Attitude of Students Towards E-learning in South-West Nigerian Universities: An Application of Technology Acceptance Model. Library Philosophy and Practice (e-journal).

Ahmad, B. (n. d.). Instructors 'and learner' Attitudes towards teaching and learning online: King Fahd University of petroleum and Minerals (KFUPM) Saudi Arabia-Case Study. International Journal of Arts \& Sciences, 
$4(8), 223-241$.

Bertea, P. (2009). Measuring students' attitude towards e-learning: A case study. Proceedings of 5th International Scientific Conference on e-Learning and Software for Education.

Bhatia, R. P. (2011). Features and Effectiveness of E-learning Tools. Global Journal of Business Management and Information Technology, 1(1), 1-7.

Bhattacharjee, B. (2008). Factors affecting computer use among older adult users: A study in the backdrop of the Florida State University. PhD Thesis, College of Information, the Florida State University. Retrieved May 5, 2013 from http://diginole.lib.fsu.edu/cgi/viewcontent.cgi?article=2284\&context=etd

Bhuasiri, W., Xaymoungkhoun, O., Zo, H., Rho, J. J., \& Ciganek, A. P. (2012). Critical success factors for e-learning in developing countries: A comparative analysis between ICT experts and faculty. Computers \& Education, 58, 843-855. http://dx.doi.org/10.1016/j.compedu.2011.10.010

Bhubaneswari, A. S., \& Padmanaban, T. (2012). Attitude of senior secondary students towards e-learning. Elixir Educational Technology, 51, 10886-10888.

Bhuvaneswari, A. S., \& Padmanaban, T. (2012). Attitude of senior secondary students towards e-learning. Elixir Educational Technology, 51, 10886-10888.

Brüchner, K. (2003). A longitudinal analysis of the development of learner-prerequisites for e-learning using a typology of computer use.

Chang, C. Y. (2002). Does computer-assisted instruction+ problem solving= improved science outcomes? A pioneer study. The Journal of Educational Research, 95(3), 143-150. http://dx.doi.org/10.1080/00220670209596584

Cheng, K. (2006). A research study on students' level of acceptance in applying e-learning for business course: A case study on a Technical College in Taiwan. Journal of American Academy of Business, 8(2), 265-272.

Colley, A. (2003). Gender differences in adolescents' perceptions of the best and worst aspects of computing at school, Computers in Hunan Behavior, 19, 673-682. http://dx.doi.org/10.1016/S0747-5632(03)00022-0

Dewan, S., \& Riggins, F. J. (2005). The Digital Divide: Current and Future Research Directions. Journal of the Association for Information Systems, 6(2), 298-337.

Dhiman, K., Birbal, S., Bhim, C. M. (2014). Attitude of University Students towards E-learning in West Bengal. American Journal of Educational Research, 2(8), 669-673. http://dx.doi.org/10.12691/education-2-8-16

Dørup, J. (2004). Experience and attitudes towards information technology among first-year medical students in Denmark: Longitudinal questionnaire survey. J. Med Internet Res, 6(1), 10.

Duran, N., Önal, A., \& Kurtuluş, C. (2006). E-Öğrenme ve kurumsal eğitimde yeni yaklaşım: Öğrenim yönetim sistemleri. Akademik Bilişim, Bildiriler Kitab. 97-101.

Egbo, O. P., Okoyeuzu, C. R., Ifeanacho, I. C., \& Onwumere, J. U. (2011). Gender perception and attitude towards e-learning: A case of business students, University of Nigeria. International Journal of Computer Application, 1(2), 135-148.

Gülbahar, Y. (2012). E-öğrenme. Ankara: PegemAkademi.

Hair, F. J., Black, C. W., Babin, J. B., Anderson, E. R., \& Totham, L. R. (2006). Multivariate Data Analysis (6th ed.). New Jersey: Pearson Prentice Hall.

Hazendar, O. (2012). The Investigation of Undergraduate Students' Information And Communication Technology Skills and attitudes to E-Learning in Terms of different Variables. (Unpublished master's thesis). Dokuz Eylul University, Educational Science Institute.

Hussain, I. (2007). A study of student's attitude towards virtual education in Pakistan. Turkish Journal of Distance Learning, 8(2), 69-79. Retrieved February 26, 2013 from http://tojde.anadolu.edu.tr/tojde26/pdf/article_6.pdf

Katz, Y. J., Evans, T., \& Francis, L. J. (1995). The reliability and validity of the Hebrew version of the Bath County computer attitude scale. Journal of Educational Computing Research, 13(3). 237-244. http://dx.doi.org/10.2190/L3VM-FLM5-4P9X-KKG1

Liaw, S. S., \& Huang, H. M. (2011). A study of investigating learners attitudes toward e-learning. 5th International Conference, 673. 
Lin, L., \& Atkinson, R. K. (2011). Using animations and visual cueing to support learning of scientific concepts and processes. Computers \& Education, 56(3), 650-658. http://dx.doi.org/10.1016/j.compedu.2010.10.007

Mehra, V., \& Omidian, F. (2011). Examining Students' Attitudes Towards E-learning: A Case from India. Malaysian Journal of Educational Technology, 11(2), 13-18.

Nassoura, A. B. (2012). Students' acceptance of mobile learning for higher education in Saudi Arabia. American Academic \& Scholarly Research Journal, 4(2).

NCTM. (2000). Principles and Standards for School Mathematics. National Council of Teachers of Mathematics, Reston, VA.

Nelasco, S., Arputharaj, A. N., \& Paul, G. L. (2007). E-Learning for Higher Studies of India, Fourth International Conference on e-learning for Knowledge-Based Society, November 18-19, Bangkok, Thailand.

Newton, R. (2003). Staff attitudes to the development and delivery of e-learning. New Library World, 104(1193), 412-425. http://dx.doi.org/10.1108/03074800310504357

Papaioannou, P., \& Charalambous, K. (2011). Principals' attitudes towards ICT and their perceptions about the factors that facilitate or inhibit ICT integration in primary schools of Cyprus. Journal of Information Technology Education, 10, 349-369. Retrieved May 4, 2013 from http://www.jite.org/documents/Vol10/JITEv10p349-369Papaioannou958.pdf

Paris, P. G. (2004). E-Learning: A study on Secondary Students' Attitudes towards Online Web Assisted Learning. International Education Journal, 5(1), 98-112. Retrieved January 20, 2013 from http://aasrc.org/aasrj/index.php/aasrj/article/download/248/188

Rafi, A., Samsudin, K. A., \& Ismail, A. (2006). On improving spatial ability though computer-mediated engineering drawing instruction. Educational Technology \& Society, 9(3), 149-159.

Richter, T., Naumann, J., \& Horz, H. (2001). Computer literacy, computer-related attitudes, and computer use among male and female students in German. Retrieved from http://mc.informatik.uni-hamburg.de/konferenzbaende/mc2001/V23.pdf

Sebnmen, K. I. (2015). Investigation of Students' Attitudes towards e-learning interms of different variables. Journal of Educational Research and Reviews, 10(1), 81-91.

Spender, D. (2001). E-learning: Are schools prepared? Proceedings of the Annual Washington conference on e-learning in a Borderless Market, 21-33.

Suri, G., \& Sharma, S. (2013). The impact of gender on attitude towards computer technology and e-learning: An exploratory study of Punjab University, India. International Journal of Engineering Research, 2(2), 132-136. Retrieved May 31, 2013 from http://www.ijer.in/ijer/publication/v2s2/paper22.pdf

Yacob, A., Kadir, A. Z. A., Zainudin, O., \& Zurairah, A. (2012). Student Awareness towards E-Learning in $\begin{array}{lllll}\text { Education. Procedia-Social and Behavioral } & \text { Sciences, }\end{array}$ http://dx.doi.org/10.1016/j.sbspro.2012.11.310

Yalman, M., GÖnen, S., \& BaȘaran, B. (2013). High School Students' Use Of Internet Technologies And Their Attitudes towards the Internet. Academic Sight, 39(18). Retrieved from http://www.akademikakis.org/eskisite/39/18.pdf

Yamamato, G. T., DEmiray, U., \& Kesim, M. (2011). Turkeye'de E-Ogrenme: Gelismeler Ve Uygulamar. Elif Publications.

Yapici, \& Akbayin. (2012). The Effect of Blended Learning Model on High School Students' Attitudes towards the Biology Course.

\section{Copyrights}

Copyright for this article is retained by the author(s), with first publication rights granted to the journal.

This is an open-access article distributed under the terms and conditions of the Creative Commons Attribution license (http://creativecommons.org/licenses/by/3.0/). 